\title{
The transient impact of the African monsoon on Plio-Pleistocene Mediterranean sediments
}

\author{
Bas de Boer ${ }^{1}$, Marit Peters ${ }^{2, a}$, and Lucas J. Lourens ${ }^{2}$ \\ ${ }^{1}$ Earth and Climate Cluster, Faculty of Science, Vrije Universiteit Amsterdam, Amsterdam, the Netherlands \\ ${ }^{2}$ Department of Earth Sciences, Faculty of Geosciences, Utrecht University, Utrecht, the Netherlands \\ ${ }^{a}$ now at: United Experts cvba, Beringen, Belgium
}

Correspondence: Lucas J. Lourens (1.j.lourens@uu.nl)

Received: 15 July 2020 - Discussion started: 4 August 2020

Revised: 23 November 2020 - Accepted: 27 November 2020 - Published: 29 January 2021

\begin{abstract}
Over the Plio-Pleistocene interval a strong linkage exists between northern African climate changes and the supply of dust over the surrounding oceans and continental runoff towards the Mediterranean Sea. Both these signatures in the sedimentary record are determined by orbital cycles influencing glacial variability on the one hand and northern African monsoon intensity on the other hand. In this paper, we use the intermediate-complexity model CLIMBER2 to simulate African climate during the Plio-Pleistocene between 3.2 and 2.3 million years ago (Ma) and compare our simulations with existing and new climate reconstructions. The CLIMBER-2 model is externally forced with atmospheric $\mathrm{CO}_{2}$ concentrations, ice sheet topography, and orbital variations, all of which strongly influence climate during the Pliocene and Pleistocene. Our simulations indicate that the records of northern Africa climate oscillate in phase with climatic precession. For the Earth's obliquity cycle, the time lag between the 41000-year component in insolation forcing and the climatic response increased after inception of Northern Hemisphere (NH) glaciation around 2.8 Ma. To test the outcome of our simulations, we have put emphasis on the comparison between the simulated runoff of grid boxes encompassing the Sahara desert and the Sahel region and the sedimentary records of marine sediment cores from ODP Site 659 (Atlantic Ocean) and ODP Site 967 (Mediterranean). In this study we will show for the first time an extended Ti/Al record of Site 967 down to 3.2 Ma. This record strongly correlates with runoff in the Sahara and Sahel regions, whereas correlation with the dust record of Site 659 is moderate and slightly improves after $\mathrm{NH}$ ice sheet inception. We investigated the transient variability of the individual and
\end{abstract}

combined contributions of the Sahel and Sahara regions and found significant transient behaviour overlapping the inception of $\mathrm{NH}$ ice sheets (2.8 Ma) and the Plio-Pleistocene transition $(2.6 \mathrm{Ma})$. Prior to $2.8 \mathrm{Ma}$, a larger contribution from the Sahara region is required to explain the variability of Mediterranean dust input. After this transition, we found that a more equal contribution of the two regions is required, representing an increased influence of Sahel runoff and wet periods.

\section{Introduction}

It has been generally accepted that climate is influenced by the orbital parameters precession, obliquity, and eccentricity since Milankovitch laid a vital foundation still used today. Ever since, astronomical calibration of climatic proxy records and sedimentary cyclicity have been used to reconstruct and understand past climatic variability over the globe (e.g. Hays et al., 1976; Hilgen, 1991; Lisiecki and Raymo, 2005). With use of the astronomical solutions of Laskar et al. (2004), the climatic response to orbital variations can be determined. Several past climate transitions are strongly linked to orbital changes, such as the inception of $\mathrm{NH}$ glaciation (Lisiecki and Raymo, 2007; Bartoli et al., 2011; Bailey et al., 2013; Willeit et al., 2015). Although radiative forcing of orbital variations is too small to force the world into or out of a glacial state with significant ice sheets, they are key to initiate ice sheet growth and to pace glaciations (e.g. Bintanja and Van de Wal, 2008; Ganopolski and Calov, 2011). If orbital variations can be seen as triggers of glaciation, internal feedback mechanisms causing changes in atmospheric concentra- 
tions of greenhouse gases (GHGs) and the enhanced growth of Northern Hemisphere (NH) ice sheets are the main amplifiers of glacial-interglacial climate change. A key driver of intensification of ice sheet changes is atmospheric concentrations of $\mathrm{CO}_{2}$ (e.g. Bartoli et al., 2011; van de Wal et al., 2011; Willeit et al., 2019), which over the past 800000 years ( $800 \mathrm{kyr}$ ) have been largely in sync with atmospheric temperature and ice volume (e.g. Lüthi et al., 2008; Stap et al., 2014).

A main transition in the recent geological past is the inception of $\mathrm{NH}$ glaciation $(\sim 2.8 \mathrm{Ma})$ (e.g. Flesche Kleiven et al., 2002 ), close to the Plio-Pleistocene transition at $\sim 2.6 \mathrm{Ma}$. The inception can be related to a drawdown of atmospheric $\mathrm{CO}_{2}$ concentrations (e.g. Willeit et al., 2015; Tan et al., 2018). Although largely driven by the $\mathrm{NH}$, the transition is a global feature, leading to Arctic cooling (Brigham-Grette et al., 2013) and cooling of tropical sea surface temperatures (Herbert et al., 2010). At that time, Earth's climate followed obliquity periodicity with symmetric glacial cycles of $\sim 41 \mathrm{kyr}$, driven by high-latitude climate variability (e.g. Venti et al., 2013). The orbitally induced variability is not limited to the high latitudes; it is also seen over the entire African continent. North African monsoonal records are linked to runoff and precipitation (e.g. Lourens et al., 2010), which persisted throughout the Pleistocene (Wagner et al., 2019). Changes are seen during the late Pliocene and midPleistocene in vegetation in northeast Africa (Rose et al., 2016), during the Pleistocene in Kenya (Lupien et al., 2018), in the West African monsoon (Kuechler et al., 2018), and in hydroclimate variability in southeastern Africa over the past 2 million years (Caley et al., 2018).

Another common association with African PlioPleistocene climate variability is early hominin evolution in eastern Africa. Orbital forcing, and its role in climate variability, has long been assumed in many paleoanthropological studies to be a strong influence on early hominins (e.g. deMenocal, 1995; Maslin et al., 2014; Joordens et al., 2019). Specific climate transitions, including the Plio-Pleistocene transition, coincide with the possible emergence or extinction of hominin species (Donges et al., 2011). The earliest hominins appear at $\sim 4.5 \mathrm{Ma}$ in Africa, and the first occurrence of the genus Homo appears around 2.8 Ma (DiMaggio et al., 2015). For example, Joordens et al. (2019) include the role of spatial distribution and geography in the study of hominin evolution and dispersal. Conditions of highly variable climate and strong seasonality during eccentricity maxima would result in isolated refugium for early hominins that would be conclusive for evolution (Trauth et al., 2007). From these refuges, the evolved hominins would then disperse inland through vegetated corridors during periods of stable climate with low seasonality during eccentricity minima (Joordens et al., 2019). However, the evolution of the hominin species throughout the Pleistocene is a highly complex process (Mounier and Mirazón Lahr, 2019).
In this paper we focus on the connection between the African monsoon, using continental runoff (linked to precipitation, evaporation, and water storage in the soil, lakes, and groundwater), and sediment and dust deposition from the African continent between 3.2 and $2.3 \mathrm{Ma}$, which includes the Plio-Pleistocene transition at 2.6 Ma. Here, we use a model of intermediate complexity, CLIMBER-2 (Petoukhov et al., 2000), to simulate climate variability. Due to its relatively low resolution and low computational costs, the model is particularly useful to simulate transient climate variability (e.g. Tuenter et al., 2005). More recent work resulted in a 5-million-year simulation (Stap et al., 2018), for which this CLIMBER-2 simulation was driven by orbital variations, ice sheet change, and atmospheric $\mathrm{CO}_{2}$ concentrations (Laskar et al., 2004; van de Wal et al., 2011; de Boer et al., 2014; Stap et al., 2018). We will compare northern African continental runoff reconstructions of CLIMBER-2 to dust records associated with the North African monsoon (ODP Site 659, Tiedemann et al., 1994; ODP Site 967, Lourens et al., 2001). For this purpose we will show for the first time the extended dust record of ODP Site 967 (Wehausen and Brumsack, 2000; Lourens et al., 2001) down to $3.2 \mathrm{Ma}$.

\section{Methodology}

\subsection{CLIMBER-2 description}

CLIMBER-2 (CLIMate-BiosphERe model) is an Earth system climate model of intermediate complexity (Petoukhov et al., 2000). The model contains simplified governing equations for processes and feedback systems of the atmosphere, oceans, sea ice, and terrestrial vegetation. This allows the model to be used for global reconstructions over very long timescales. The CLIMBER-2 model has a low spatial resolution; the longitude is divided into seven sectors each consisting of approximately $51^{\circ}$ longitude and the latitude into steps of $10^{\circ}$ each (Fig. 1). The land-ocean fraction for each grid box varies accordingly to the shape of each continent. The CLIMBER-2 model has a temporal resolution of $1 \mathrm{~d}$, which is averaged to capture annual averaged output. For the analysis we have used 1 kyr running mean output from CLIMBER-2.

The atmosphere component of CLIMBER-2 shares many features with more sophisticated models (Petoukhov et al., 2000). The model is comprised of vertically averaged prognostic equations to model temperature and water vapour, as well as to reconstruct horizontal transport and radiative fluxes. Specific humidity is assumed to be exponential in the vertical profile, and the wind velocity is based on both geostrophic and ageostrophic components. It is assumed that the Hadley, Ferrel, and polar cells are robust and must have also existed under different climatic conditions. Within CLIMBER-2 six surface types can exist: sea ice or open water for ocean and ice sheets, grassland, forest, and desert for land. These are all calculated separately and multiple types can coexist within one grid box. For example, grid boxes 11 


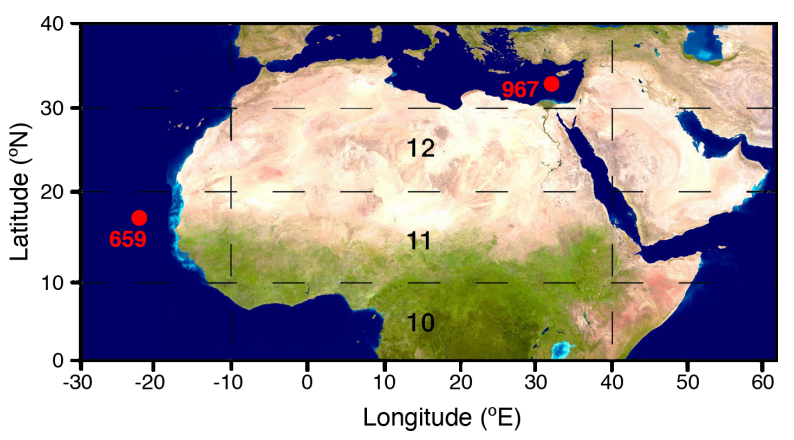

Figure 1. Map of the study area, with the background showing vegetation cover. Dashed lines indicate the grid boxes of CLIMBER-2, with the number the grid boxes used in this study. Red dots indicate the location of the sites.

and 12 are completely land boxes, but grid box 10 is $40 \%$ ocean and $60 \%$ land (Fig. 1). CLIMBER-2 further includes a three-basin ocean model based on Stocker et al. (1992). It describes the zonally averaged flow of water and the evolution of temperature and salinity in the Atlantic, Indian, and Pacific basins, which are connected through the Southern Ocean. It consists of 20 uneven levels and an upper mixed layer of $50 \mathrm{~m}$ using a time step of $5 \mathrm{~d}$ and a latitudinal resolution of $2.5^{\circ}$. The vegetation module VECODE is a dynamical global vegetation model that is based on the classification by Brovkin et al. (1997), who provided a continuous bioclimatic classification. This component describes the spatial behaviour of vegetation and its corresponding carbon fluxes. It is assumed that vegetation cover is in equilibrium with climate. Therefore, changes in vegetation will affect the albedo, roughness length, and transpiration of the grid box, resulting in a changing climate. The temporal resolution of the vegetation module is 1 year. The planetary albedo of a grid box is calculated based on the amount of snow and vegetation cover, as well as the degree of cloudiness for every grid box. A two-layer soil model is also incorporated, in which the upper soil layer is determined by precipitation, evaporation and transpiration, the melting of snow, and runoff and drainage. In contrast, runoff and precipitation also depends on the water content and amount of vegetation that grows on the upper soil layer.

\subsection{Setup of CLIMBER-2 experiments}

This study focuses specifically on the northern African continent (Fig. 1), for which we have used the output of 5-millionyear simulations of CLIMBER-2. To achieve such a long simulation, the model is forced with changes in orbital parameters, atmospheric $\mathrm{CO}_{2}$, and ice sheets (Stap et al., 2018). For the orbital variations the solution from Laskar et al. (2004) is used, describing variations of eccentricity, climatic precession, and obliquity (Fig. 2a and b). Ice volume reconstructions are enforced on land surface points of CLIMBER2 , influencing albedo and surface elevation. The ice sheets are taken from a global simulation by de Boer et al. (2014), who calculated global ice volume changes based on the LR04 benthic $\delta^{18} \mathrm{O}$ stack by Lisiecki and Raymo (2005), shown here in Fig. 2c. They used an inverse modelling approach to derive ice volume (Fig. 2d) as well as surface-air and deepocean temperature. For the CLIMBER-2 model, an updated version of the proxy data composition by van de Wal et al. (2011) is used for $\mathrm{CO}_{2}$ concentrations (Stap et al., 2018). To reconstruct $\mathrm{CO}_{2}$ variations (Fig. 2e) the same approach was used as in van de Wal et al. (2011) by calibrating $\mathrm{CO}_{2}$ records against global temperature change. The calibration here is based on the temperature simulation associated with the ice sheet simulation also used in the CLIMBER-2 model. Other variations in greenhouse gases are not taken into account in the model. This way the simulation of CLIMBER-2 is consistent with the forcing, driven by Laskar et al. (2004) insolation and climatic forcing records on the LR04 age scale (Lisiecki and Raymo, 2005).

Using the three different climatic records, four different climate model simulations are performed using only (i) orbital variations (indicated by "O"), (ii) orbital and greenhouse gas $\mathrm{CO}_{2}(\mathrm{OG})$, (iii) orbital and ice sheets (OI), and (iv) all records (OIG). These four different simulations are used here to analyse variations in African runoff. When forcing records are kept constant we use the present-day ice sheets and a pre-industrial level of $280 \mathrm{ppm}$ for $\mathrm{CO}_{2}$.

\subsection{Climatic dust records}

We will compare the output of CLIMBER-2 with three different sites presenting dust or terrestrial variations driven by climate variability over the African continent (Fig. 1). The core drilled at ODP Site 967 is an exceptional record of paleoclimate with detailed cyclic variability (Lourens et al., 2001). It is located in the eastern Mediterranean Sea, south of Cyprus. The interval consists of six sapropels, also analysed through colour reflectance (Lourens et al., 2001). The sapropels are cyclostratigraphically correlated with the sections of Hilgen (1991), Lourens et al. (1996), and Kroon et al. (1998), which all originate from different sites within the Mediterranean. The Ti/Al ratio proxy is used to reconstruct variations in climate, whereby variability in $\mathrm{Ti} / \mathrm{Al}$ represents variation in the relative contribution of aeolian (i.e. Ti-rich dust particles) and fluvial (i.e. Al-rich suspended clay components) terrigenous input in the sediment core (Wehausen and Brumsack, 2000; Lourens et al., 2001; Konijnendijk et al., 2014; Grant et al., 2017). It is suggested that Saharan dust is a prior contributor to the aeolian flux, while a large proportion of the fluvial input originates from the Nile. Hence, low $\mathrm{Ti} / \mathrm{Al}$ values indicate humid conditions, for example during periods of sapropel formation in the eastern Mediterranean, and high $\mathrm{Ti} / \mathrm{Al}$ values correspond to more arid conditions in the northern part of the African continent (Wehausen and Brumsack, 2000; Lourens et al., 2001). An astronomically tuned $\mathrm{Ti} / \mathrm{Al}$ time series was established for 

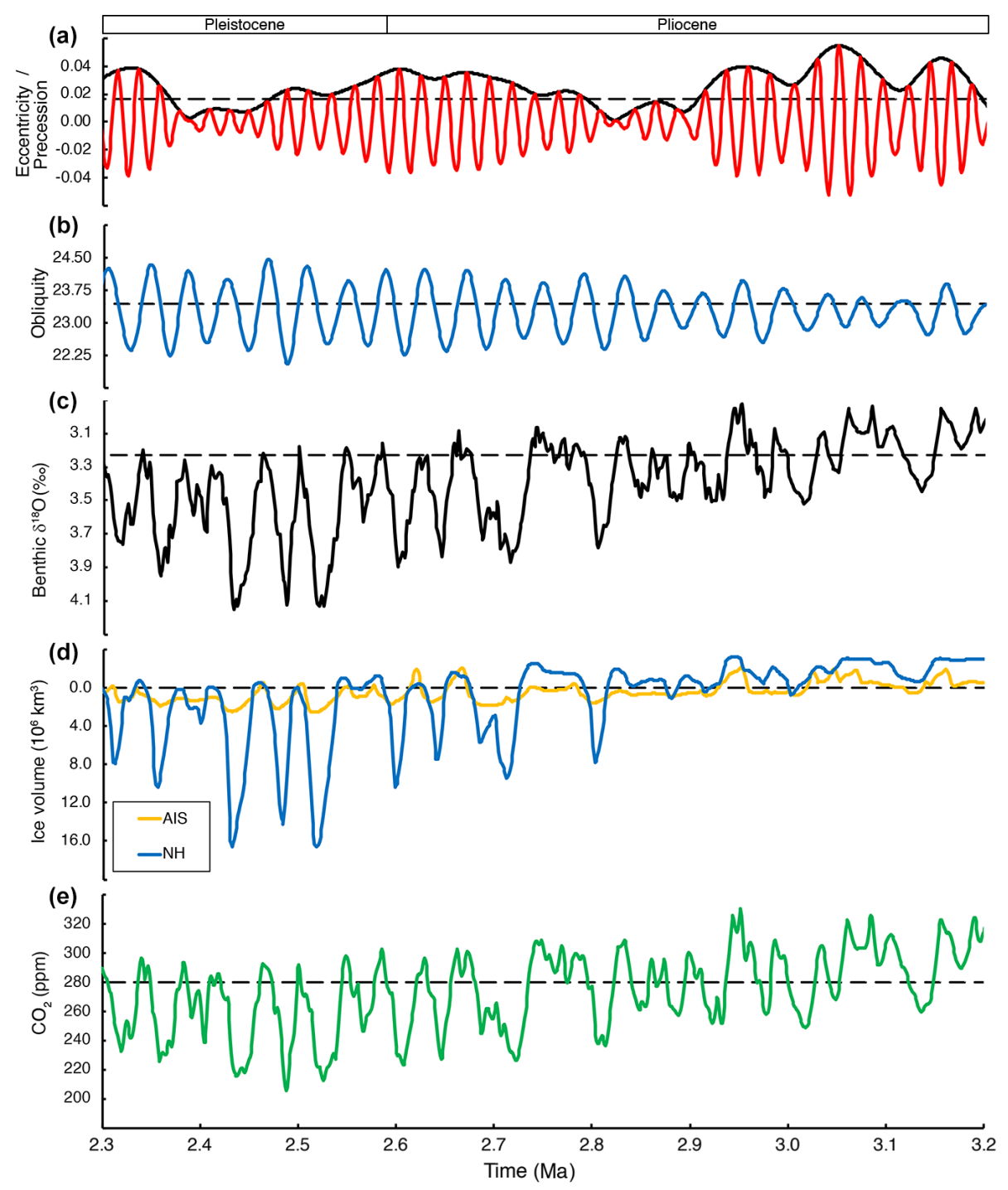

Figure 2. Climatic forcing records used as input for CLIMBER-2 over the time studies from 3.2 to 2.3 Ma. (a) Eccentricity in black, climatic precession in red, and (b) obliquity in blue (Laskar et al., 2004). (c) The benthic LR04 $\delta^{18} \mathrm{O}$ record (Lisiecki and Raymo, 2005) used for reference. (d) Global ice volume reconstruction (in $10^{6} \mathrm{~km}^{3}$ on land) for the Antarctic Ice Sheet (AIS) in orange and the total NH in blue from de Boer et al. (2014). The $y$ axis is reversed for (c) and (d), with cold climate below. (e) Atmospheric $\mathrm{CO}_{2}$ concentrations (in parts per million; ppm) generated using the methodology described in van de Wal et al. (2011).

the 2.9-2.4 Ma time interval by correlating minimum (maximum) values in the $\mathrm{Ti} / \mathrm{Al}$ record with their representative maximum (minimum) values in the Laskar et al. (2004) summer insolation curve at $65^{\circ} \mathrm{N}$ latitude (Lourens et al., 2001). Here, we extend the tuned $\mathrm{Ti} / \mathrm{Al}$ time series down to $3.2 \mathrm{Ma}$ using unpublished $\mathrm{Ti} / \mathrm{Al}$ data generated using similar procedures as described in Lourens et al. (2001). All samples were freeze-dried and then ground and homogenised in an agate ball mill. For X-ray fluorescence (XRF) analysis, $600 \mathrm{mg}$ of the sample powder was mixed with $3600 \mathrm{mg}$ lithium tetraborate $\left(\mathrm{Li}_{2} \mathrm{~B}_{4} \mathrm{O}_{7}\right.$, Spektromelt), pre-oxidised at $500{ }^{\circ} \mathrm{C}$ with $\mathrm{NH}_{4} \mathrm{NO}_{3}$, and fused to glass beads that were subsequently analysed with a Philips PW 2400 X-ray spectrometer. Ana- lytical precision was determined by parallel analysis of one international (GSR-6) and several in-house standards and was better than $1 \%$ for $\mathrm{Al}$ and $\mathrm{Ti}$.

ODP Site 659 is located on top of the Cape Verde Plateau, northwest of Africa (Fig. 1). Its dust record encompasses the past $5 \mathrm{Myr}$ and is mostly influenced by the African easterly jet stream, which transports dust from the SaharaSahel region towards the Atlantic Ocean (Tiedemann et al., 1994). We have re-tuned the dust record of ODP Site 659 (Wang et al., 2010) to the LR04 benthic stable isotope stack (Lisiecki and Raymo, 2005). As mentioned in Wang et al. (2010), the data for the last $2.6 \mathrm{Myr}$ follow the same age scale, which is actually included in the LR04 stack (for ben- 
thic $\delta^{18} \mathrm{O}$ ). Between 5.2 and $2.6 \mathrm{Ma}$ the data are re-tuned to minima in the Laskar et al. (2004) $65^{\circ} \mathrm{N}$ insolation curve.

\section{Orbital pacing of CLIMBER-2 modelled runoff}

Runoff over the northern African continent as modelled in CLIMBER-2 largely results from the difference between precipitation and evaporation over land, although water can also be stored in the soil, lakes, and groundwater. As can be seen in Fig. 1, grid box 12 mainly covers the Sahara, whereas grid box 11 includes the Sahel region, which is more dominated by grassland. The variations of vegetation coverage for both grid boxes over time show similar patterns as illustrated in Fig. 3. Clearly, during the studied time interval from 3.2 to 2.3 Ma the Sahara region (Fig. 3a) is dominated by desert, which is largely replaced with grassland when precipitation is high. Although the Sahel region (Fig. 3b) is largely covered with grassland, it is partially covered with trees and a reduction in desert during precession minima. Both grid boxes show high variability of the vegetation fraction but also show a clear linkage to the present-day coverage of partially desert and vegetation for grid box 11 and desert for grid box 12 (Fig. 1).

The difference between the two grid boxes is clearly represented by the variation in runoff over the Plio-Pleistocene transition (Fig. 4a). It is evident that the minimum runoff of grid box 11 is approximately the equivalent of the maximum runoff of grid box 12. Grid box 11 has large variations in amplitude, with runoff maxima occurring during precession minima (Fig. 4a). For the Sahel region, the runoff is strengthened following the African summer monsoon, driven by an increase in $\mathrm{NH}$ insolation. The increase in precipitation causes an increase in trees, which replaces desert and grass (Fig. 3b). This enhances evaporation, which is stronger than for grassland, causing the peaks in runoff. In contrast, the runoff values of grid box 12 (Sahara desert) do not increase by the strengthened monsoon but show peaks of low runoff during precession maxima. Although precipitation is enhanced during the summer monsoon when the air from the Atlantic Ocean reaches land, higher temperatures provide more room for water to evaporate, in combination with an increase in grass cover (Fig. 3a) In the case of grid box 12, this additional precipitation is therefore compensated for by an increase in evaporation. Also, during precession maxima precipitation is reduced and vegetation disappears, which leads to a strong decrease in evaporation and minima in runoff.

The clear dominance of precession variability during this time interval is well depicted by the global power spectra of both regions (Fig. 5a). Over time, the evolutive power spectra confirm the dominance of precession, although it is lower during eccentricity minima (Fig. 4b and c). Clearly a highlatitude influence is more present for the Sahara (grid box 12), showing an increased obliquity power after inception of NH glaciation (Fig. 4b).
The influence of precession variability on African runoff in both regions is strongly present in all four CLIMBER-2 experiments $(\mathrm{O}, \mathrm{OG}, \mathrm{OI}$, and $\mathrm{OIG})$ over the Plio-Pleistocene transition (Table 1). For all runs the lag to climatic precession is minimal, showing that for this particular frequency and interval, the modelled runoff is largely in sync with climatic precession. In the case of obliquity, the lag is also small for the $\mathrm{O}$ and $\mathrm{OG}$ experiments, not including ice sheet changes. However, when ice sheet changes are included in the CLIMBER-2 OI and OIG simulations, we see an increase in the lag by about $1.5-2 \mathrm{kyr}$ relative to the runs with constant ice sheet topography. This shift can be attributed to the imposed lag in the tuning of the LR04 benthic $\delta^{18} \mathrm{O}$ data when calibrating the depth-age scale. The time lag between obliquity (41 kyr) and its related frequency component in the LR04 stack is gradually increased from $3 \mathrm{kyr}$ prior to $3 \mathrm{Ma}$ towards 5-6 kyr up to $1.2 \mathrm{Ma}$. This follows from an anticipated slower response time of the growth of larger Pleistocene ice sheets (Lisiecki and Raymo, 2005). Also, the power of the obliquity frequency of runoff is increased in the $\mathrm{OI}$ and OIG relative to the $\mathrm{O}$ and OG simulations.

\section{Comparison of North African runoff with offshore sediment records}

The orbital periodicity is presented by the power spectra of Sites 967 and 659 (Fig. 5b). A strong presence of precession and obliquity is seen for both the Ti/Al record of Site 967 (Lourens et al., 2001) and the dust record for the re-tuned age model of Site 659.

We have also analysed the coherence and phase lag for the precession frequencies from the runoff and dust records. For this we have filtered the precession frequency of $1 / 23 \mathrm{kyr}^{-1}$ $\left(0.0435 \pm 0.003 \mathrm{kyr}^{-1}\right)$ for each record and compared it relative to precession during the full time interval from 3.2 to $2.3 \mathrm{Ma}$. Coherence is high for runoff from grid boxes 11 and 12 and for the Ti/Al record (all above 0.99), with a phase lag of about 200 years. For the re-tuned dust record of Site 659 the coherence is 0.95 and the phase lag is $\sim 800$ years.

The correlation with the runoff output from CLIMBER2 is strongest with the Ti/Al record from the Mediterranean (Table 2). The dust record from Site 659 shows, in contrast, a good correlation with runoff from box 12 (Sahara) and a much weaker correlation with box 11 (Sahel).

Note that for the correlation we have used the inverse relationship, correlating high runoff with low dust output, and corrected for the time lags of $1 \mathrm{kyr}$ for the chronologies of ODP Site 659.

\subsection{North African runoff and sapropel formation in the Mediterranean}

The influence of the North African monsoon and its relation to orbital forcing is also clear through the presence of Mediterranean sapropels (e.g. Hilgen, 1991; Lourens et al., 


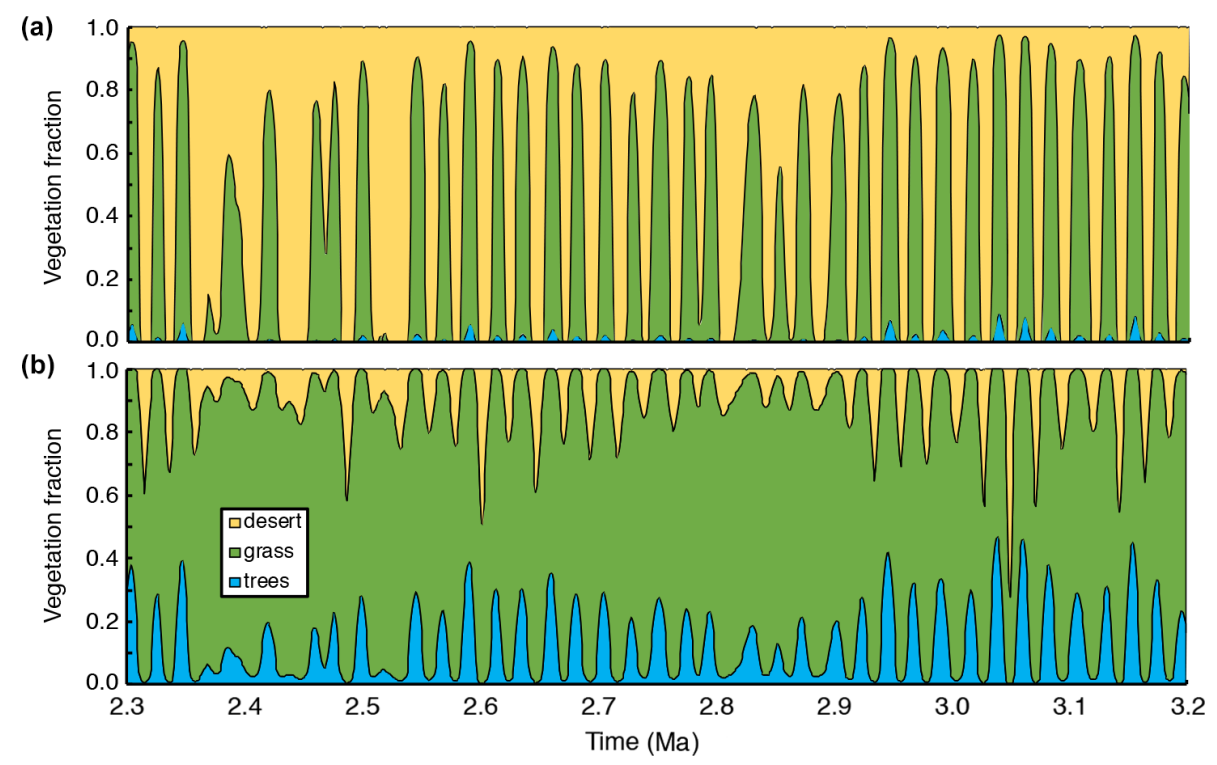

Figure 3. OIG vegetation fractions over (a) grid box 12 (Sahara) and (b) grid box 11 (Sahel). The fraction of desert is given in yellow; grass is green and trees are blue.
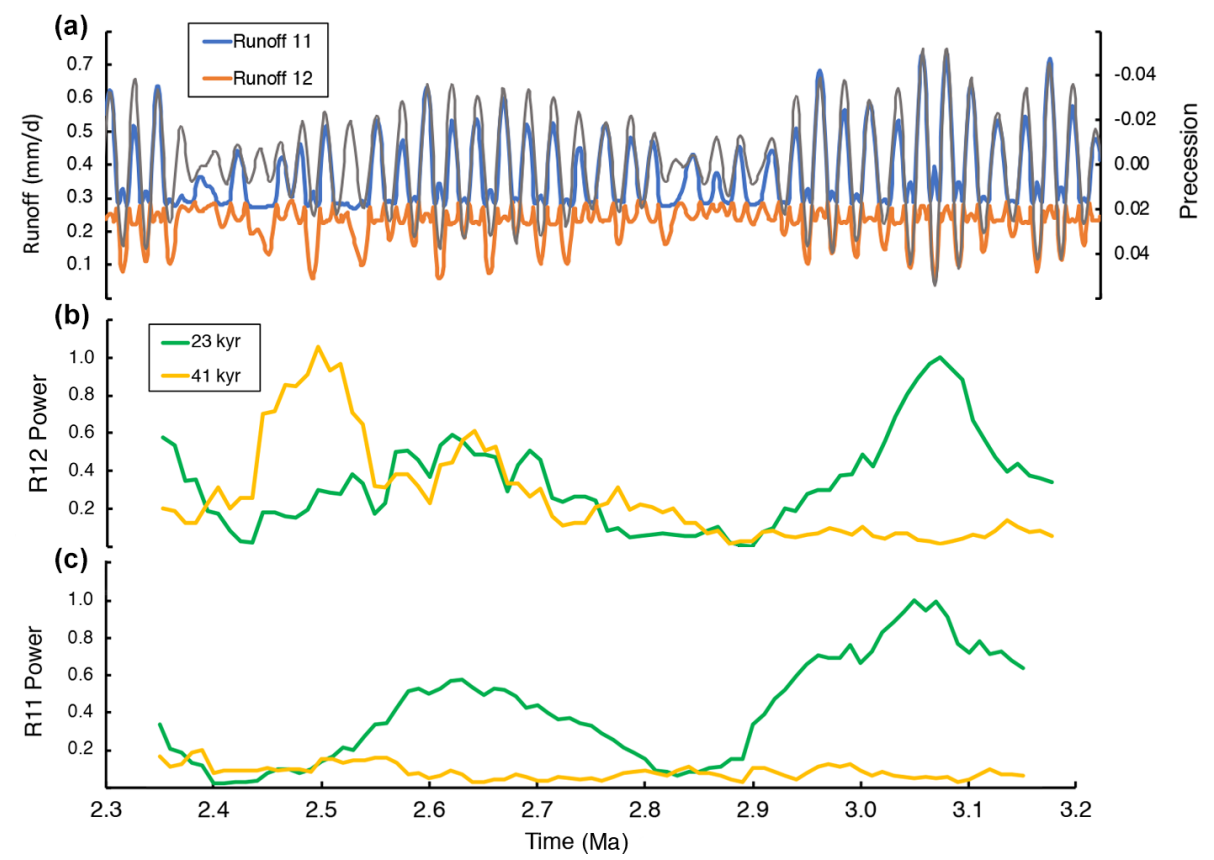

Figure 4. OIG runoff over grid boxes 11 (blue) and 12 (orange), as given in Fig. 1 in millimetres per day. The background shows climatic precession (Laskar et al., 2004), with the scale given on the right $y$ axis that is reversed (grey). The evolutive normalised power spectrum is given for (b) grid box 12 and (c) grid box 11 for $23 \mathrm{kyr}$ (green) and $41 \mathrm{kyr}$ (yellow) using a time window of $100 \mathrm{kyr}$.

2001). Sapropels are organic-rich sedimentary layers, resulting from anoxic events caused by an increase in runoff that is associated with a strong summer monsoon. Over the PlioPleistocene transition we compare the $\mathrm{Ti} / \mathrm{Al}$ record with CLIMBER-2 runoff from grid boxes 11 and 12 (Fig. 6). Clearly, both the wet and dry periods correspond well to the simulated runoff, although the runoff maxima from grid box
11 (Sahel) largely link to low Ti/Al peaks, and runoff minima of grid box 12 (Sahara) overlay maxima of the $\mathrm{Ti} / \mathrm{Al}$ record. The sapropel layers that have been found in ODP Site 967 (Emeis et al., 1996; Kroon et al., 1998; Lourens et al., 2001) can be correlated with the high runoff peaks of grid box 11 . This shows that the Sahel region not only indicates increased African monsoon phases, but also correlates with the corre- 
Table 1. Calculated time lags in thousands of years (kyr) between orbital frequencies and runoff over grid boxes 11 and 12 for the full period 3.2 to $2.3 \mathrm{Ma}$. Frequencies are extracted from the data with a Gaussian filter for precession at 23 kyr $(0.0435 \pm 0.003)$ and for obliquity at $41 \mathrm{kyr}(0.0245 \pm 0.003)$. Data were analysed with AnalySeries (Paillard et al., 1996) using a Blackman-Tukey spectral analysis with a Parzen window and $90 \%$ lags. CLIMBER-2 experiments are as follows. O: orbital; OG: orbital and $\mathrm{CO}_{2}$; OI: orbital and ice sheets; OIG: orbital, $\mathrm{CO}_{2}$, and ice sheets.

\begin{tabular}{lrrrrrrrr}
\hline Period & R11-O & R11-OG & R11-OI & R11-OIG & R12-O & R12-OG & R12-OI & R12-OIG \\
\hline Precession (23 kyr) & 0.194 & 0.221 & 0.230 & 0.248 & -0.188 & -0.163 & 0.184 & 0.228 \\
Obliquity (41 kyr) & 0.728 & 1.135 & 2.697 & 2.604 & 0.497 & 0.772 & 2.390 & 2.667 \\
\hline
\end{tabular}

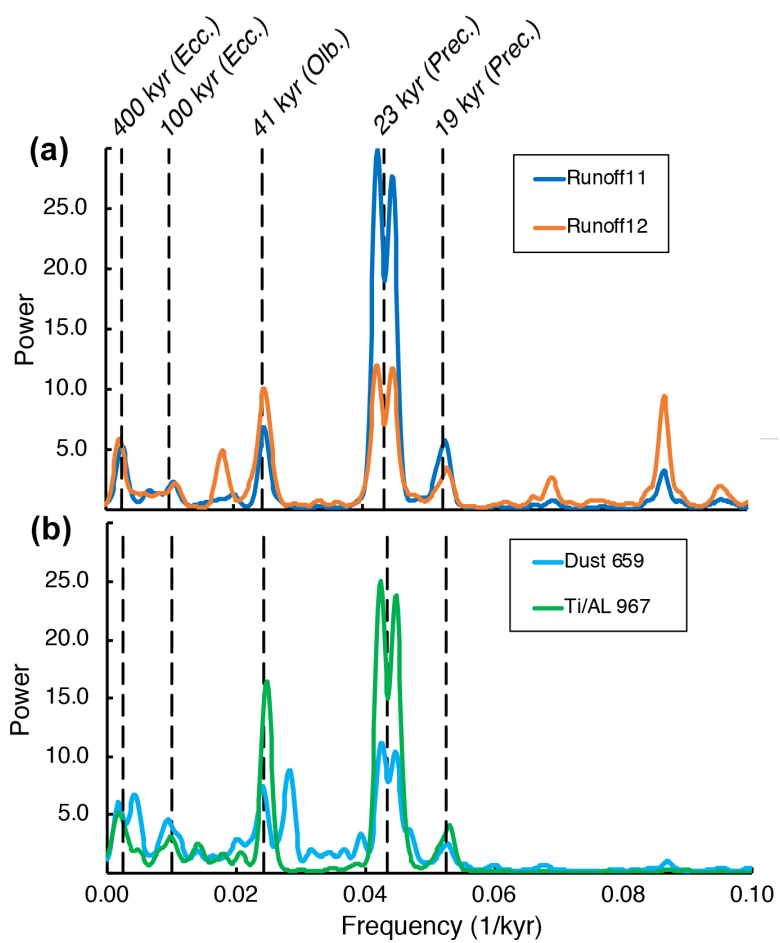

Figure 5. Normalised power spectra over the period 3.2 to $2.3 \mathrm{Ma}$ for (a) runoff of grid boxes 11 (blue) and 12 (orange), as well as (b) of Ti/Al from Site 967 (green) and dust from Site 659 (light blue). The Site 659 dust record is re-tuned to the LR04 benthic stable isotope stack (Lisiecki and Raymo, 2005). Power spectra are created with AnalySeries (Paillard et al., 1996) using a BlackmanTukey spectral analysis with a Parzen window and $90 \%$ lags. Vertical dashed lines indicate the dominant orbital periods of 400 and $100 \mathrm{kyr}$ (eccentricity), $41 \mathrm{kyr}$ (obliquity), and 23 and $19 \mathrm{kyr}$ (precession).

sponding sapropel layers in the Mediterranean Sea. The Sahara region correlates with the high $\mathrm{Ti} / \mathrm{Al}$ values, indicating dry phases. These dry phases of the Sahara region can therefore be correlated with the marls, i.e. periods of high dust flux, between the sapropel layers of ODP Site 967 (Lourens et al., 2001).

Although the general pattern correlates very well (Table 2), there are also clear differences between the CLIMBER-2 simulations and the Ti/Al record. For example,
Table 2. Correlation of runoff from grid boxes 11 and 12 with the sedimentary records at Sites 967 and 659. Correlation is performed over the full period from 3.2 to $2.3 \mathrm{Ma}$, and all data are interpolated on a 1 kyr time step.

\begin{tabular}{lrr}
\hline Region & Ti/Al 967 & Dust 659 \\
\hline Runoff 12 (Sahara) & 0.586 & 0.560 \\
Runoff 11 (Sahel) & 0.662 & 0.361 \\
\hline
\end{tabular}

the relative amplitude variations of the humid phases are not always the same. Sapropel 64 is clearly enhanced by obliquity, whereas the runoff at this time has a relatively low maximum. On the other hand, runoff is significantly high during the formation of sapropel 65, which is one of the less distinct sapropel layers. This is remarkable, as large runoff in northern Africa would suggest a lower Ti/Al ratio due to more riverine input in the Mediterranean Sea. The most apparent discrepancy between the Ti/Al record and the CLIMBER2-simulated runoff is shown during the $400 \mathrm{kyr}$ eccentricity minimum around 2.8 and 2.4 Ma. During these long-term eccentricity nodes, the $\mathrm{Ti} / \mathrm{Al}$ record suggests drier climate conditions on average in northern Africa than indicated by the model simulations. In this time interval, both the runoff amplitudes are significantly lower and the variations for grid box 12 are even out of phase with sapropel layers S68 and S69 (Fig. 6).

\subsection{Combined runoff and overall correlation}

It appears that the influence of wetter periods (grid box 11) overshadows the effect of dry periods (grid box 12) given that the amplitude variation of grid box 12 (Sahara) is significantly less than runoff from grid box 11 (Sahel). Both regions include the catchment area of the Nile (e.g. Bosmans et al., 2015b), and hence a combination of runoff from the two sites would be more suited for a comparison with the $\mathrm{Ti} / \mathrm{Al}$ record. We have investigated multiple combinations of runoff from grid boxes 11 and 12 and compared these with the two sedimentary records of Sites 967 and 659 over the full period from 3.2 to $2.3 \mathrm{Ma}$ (Fig. 7). For each grid box, we have used a scaling varying between 0.0 and 1.0 in order to cover all possible combinations of the two records, including 


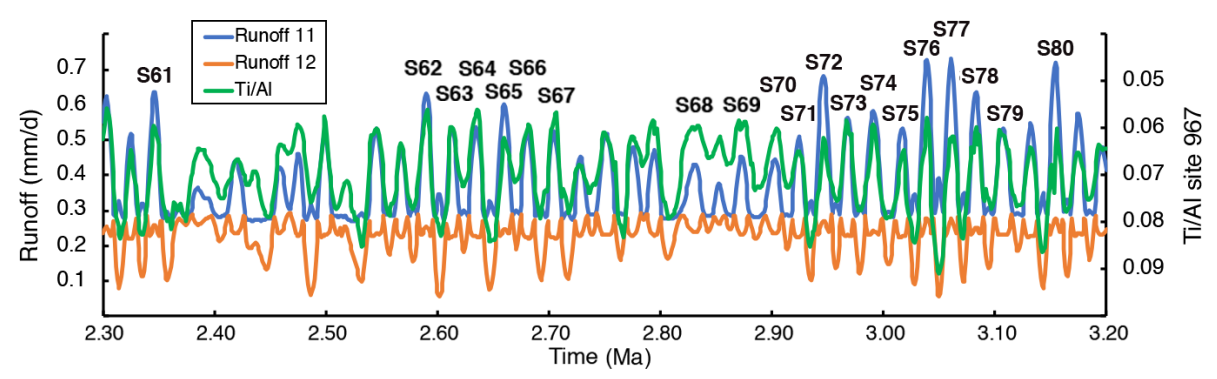

Figure 6. A comparison between CLIMBER-2 runoff from grid boxes 11 (blue) and 12 (orange) and the Ti/Al record from Site 967 (green) from 3.2 to 2.3 Ma. Sapropel layers are labelled (S61 to S80) as adopted from Kroon et al. (1998) and Lourens et al. (2001), corresponding to Ti/Al minima and runoff maxima. Note that the left $y$ axis for the $\mathrm{Ti} / \mathrm{Al}$ is reversed, with wet phases on top.

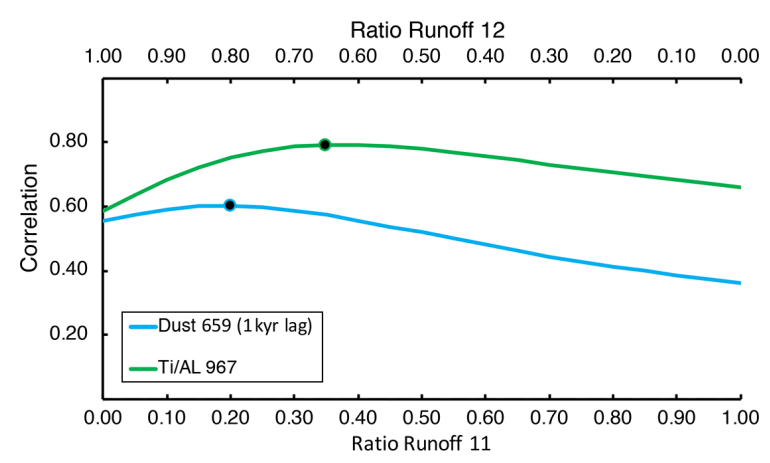

Figure 7. Correlation of the combined output of runoff from grid boxes 12 (top $x$ axis) and 11 (lower $x$ axis). For example, 0.5 and 0.5 indicate a runoff record consisting of $50 \%$ runoff 11 and $50 \%$ runoff 12. For each created record the correlation is computed over the full time period of 3.2 to 2.3 Ma. Green: with Ti/Al of Site 967; light blue: with dust from Site 659 (lag of $1 \mathrm{kyr}$ ). The dots indicate the maximum correlation for the $\mathrm{Ti} / \mathrm{Al}$ record of $0.35 \mathrm{R} 11+$ $0.65 \mathrm{R} 12$ (0.792) and for Site 659 of $0.2 \mathrm{R} 11+0.8 \mathrm{R} 12$ (0.602).

the individual correlation. For both the Mediterranean (Site 967) and the Atlantic Ocean (Site 659) a combined runoff record provides the best correlation with the data.

The combination of $35 \%$ runoff 11 plus $65 \%$ runoff 12 has a correlation of 0.792 with the $\mathrm{Ti} / \mathrm{Al}$ record, and $20 \%$ runoff 11 plus $80 \%$ runoff 12 has a correlation of 0.602 with the dust record of Site 659. For both sites this correlation is higher than with the individual grid boxes, as shown in Table 2 and Fig. 7. The correspondence between the combined runoff record and the $\mathrm{Ti} / \mathrm{Al}$ data is high throughout the PlioPleistocene time interval (Fig. 8a). For separate time windows of $100 \mathrm{kyr}$ the correlation is consistently high, with a maximum value of 0.930 between 2.6 and $2.5 \mathrm{Ma}$ and a minimum value of 0.749 between 2.5 and $2.4 \mathrm{Ma}$. For the dust record of Site 659 the correlation is less pronounced for the individual records (Table 2). When we analyse the $100 \mathrm{kyr}$ time window the correlation with the combined runoff record (Fig. 8b) varies between -0.103 and 0.873 , which only shows a negative correlation between 2.9 and $2.8 \mathrm{Ma}$ and an overall high correlation between 0.524 for $2.7-2.6 \mathrm{Ma}$ and 0.873 for 2.8 to $2.7 \mathrm{Ma}$.

Although correlation is high for some time intervals, there is a non-linear behaviour between runoff, which results from precipitation and evaporation, and dust peaks from Site 967 and Ti/Al from Site 659. High runoff peaks do not always correspond to high dust or $\mathrm{Ti} / \mathrm{Al}$ signatures in the records. We have illustrated this by comparing the high and low peaks of $\mathrm{Ti} / \mathrm{Al}$ and the dust records with the corresponding peaks of the runoff records (Fig. 8c and d). For both the high (orange) and low (light blue) peaks of $\mathrm{Ti} / \mathrm{Al}$ (Fig. 8c) a clear trend is visible. In contrast, for the dust record (Fig. 8d), the high peaks (red) show a more linear trend compared to the low peaks (blue). Nonetheless, correlation coefficients are moderate to low for all comparisons.

Besides the good correlation during most $100 \mathrm{kyr}$ intervals, the evolutive power of the precession frequency in particular (blue curve in Fig. 9a and b) also shows strong similarity to the precession power in CLIMBER-2 runoff (Fig. 4b and c). A clear lowering is seen for the eccentricity minimum from 2.8 to 2.9 Ma. For the dust record of Site 659, besides the eccentricity minima a dip in the $23 \mathrm{kyr}$ power around $\sim 2.6 \mathrm{Ma}$ is seen (Fig. $9 \mathrm{~b}$ ), for which we would expect $23 \mathrm{kyr}$ power to stay high following the $400 \mathrm{kyr}$ eccentricity maximum (Fig. 2a). This also underlines the non-linear link between dust and runoff, as illustrated in Fig. 8.

\subsection{Transient impact of runoff to the Mediterranean}

The strong link between simulated runoff and the Ti/Al record of the Mediterranean is a feature that is very persistent through the Plio-Pleistocene transition (Fig. 8a). Although the strongest correlation over the whole period is found for the combination of $35 \%$ runoff 11 plus $65 \%$ runoff 12 , correlation is generally high for other combinations as well. This provides us with an opportunity to look not only at the temporal correlation of individual sites, but also how the contributions of runoff from the regions impact the Ti/Al record over time. Figure 10a presents this for $100 \mathrm{kyr}$ time windows, showing for each window separately the combination of runoff from grid boxes 11 and 12 with the highest corre- 

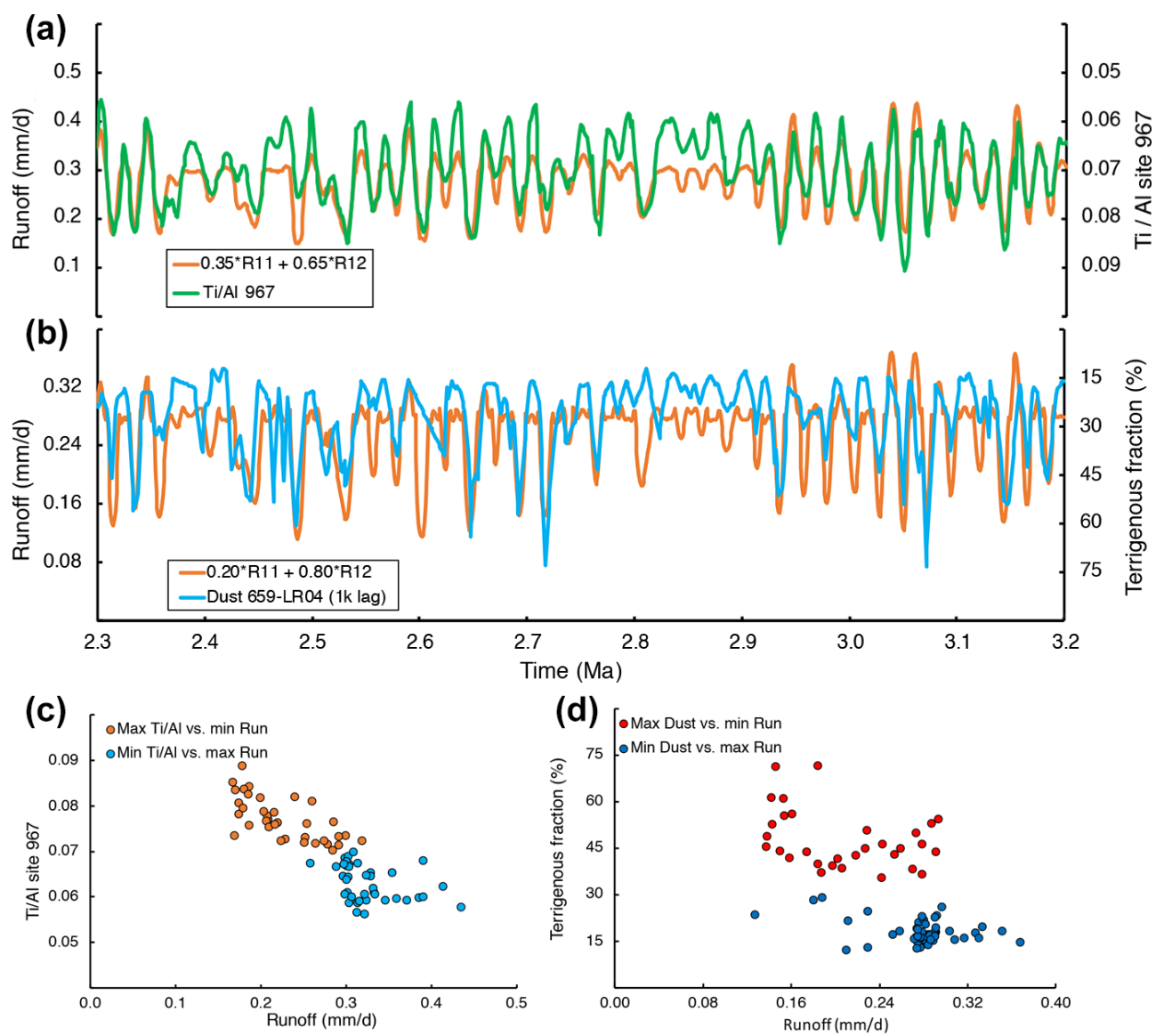

Figure 8. A comparison between CLIMBER-2 combined runoff output that correlates the highest as given in Fig. 7. (a) Combined runoff of $35 \%$ runoff 11 plus $65 \%$ runoff 12 (orange) and the Ti/Al record of Site 967 (green). (b) Combined runoff of $20 \%$ runoff 11 plus $80 \%$ runoff 12 (orange) and the dust record of Site 659 (light blue) re-tuned to the LR04 age scale. In (a) and (b), for both sedimentary records the $y$ axis is given on the right and is reversed. (c) A comparison of the high (orange) and low (light blue) peaks of Ti/Al versus runoff from panel (a). Peaks are selected for Ti/Al values above and below 0.07. (d) A comparison of the high (red) and low (blue) peaks of dust versus runoff from panel (b). Peaks are selected for dust values above and below 35 .

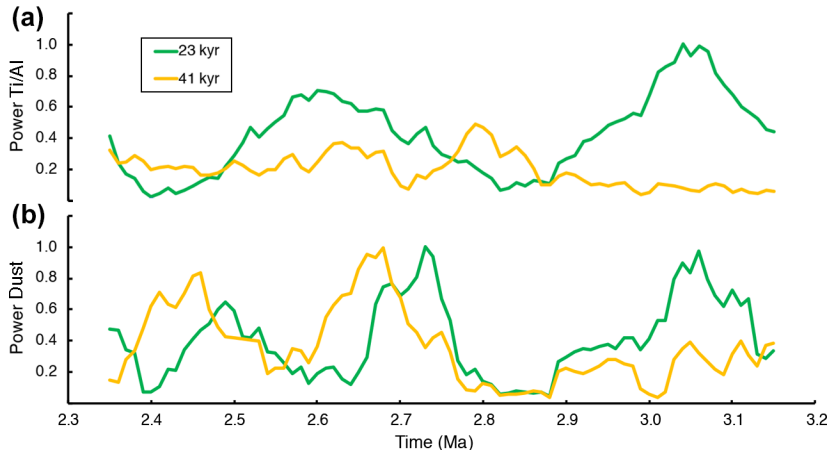

Figure 9. Evolutive normalised power spectrum for (a) $\mathrm{Ti} / \mathrm{Al}$ of Site 967 and (b) dust of Site 659 for $23 \mathrm{kyr}$ (green) and $41 \mathrm{kyr}$ (yellow) using a time window of $100 \mathrm{kyr}$. lation (illustrated in Fig. 10b by the grey line) and depicting the transient relationship of runoff over northern Africa to sediment deposition in the Mediterranean.

There is a clear transition present, coinciding with the increase in NH glaciation (Fig. 2d), at around 2.8 Ma. Before this time, the correlation is highest for a more dominant contribution of the Sahara region (grid box 12 in orange), close to the overall coherence with $35 \%$ of grid box 11 and $65 \%$ of grid box 12. After $2.8 \mathrm{Ma}$, the highest correlation is found for a more equal contribution of $50 \%$ from each of the two regions. We found no strong trends in runoff for either region.

The catchment area of the Nile stretches more south than regions 12 and 11, starting around Lake Victoria (the blue lake in Fig. 1 at the Equator; $33^{\circ}$ E). Therefore, we also checked correlation with runoff from region 10, using combinations with runoff from regions 11 and 12. Surprisingly, the individual correlation of runoff from region 10 with the $\mathrm{Ti} / \mathrm{Al}$ record from 3.2 to $2.3 \mathrm{Ma}$ is higher $(0.720)$ than that of regions 11 and 12 (Table 2). Before $2.8 \mathrm{Ma}$, correlation 


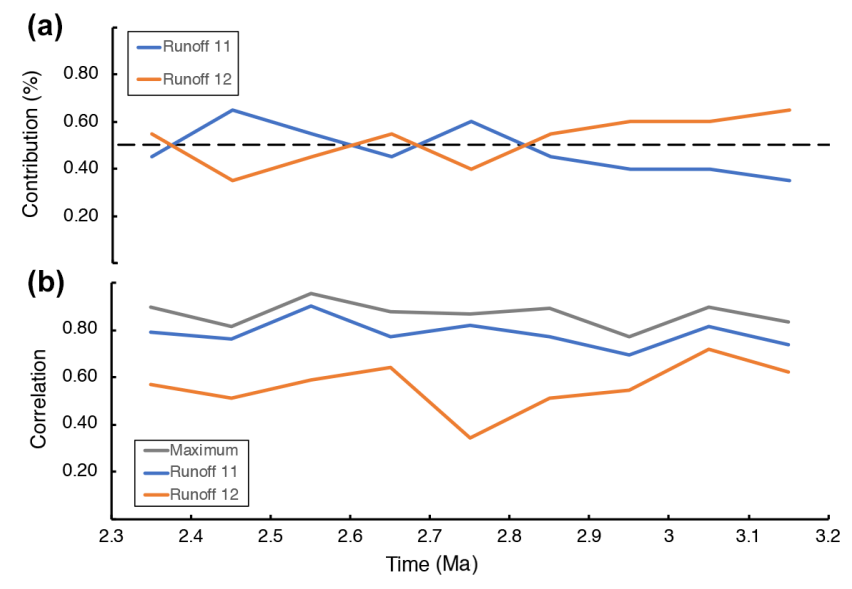

Figure 10. Transient contribution of runoff from grid boxes 11 and 12 to Mediterranean dust input. For each time window of $100 \mathrm{kyr}$, all combinations of the two grid boxes (as in Fig. 7) are correlated with the Ti/Al record of Site 967. (a) The contribution of both grid boxes (blue for runoff 11 and orange for runoff 12) is given, corresponding to the maximum correlation within that time frame, as shown by the grey line in panel (b). (b) The maximum correlation within each $100 \mathrm{kyr}$ time window is given in grey, corresponding to the contributions shown in panel (a). Correlation of the individual grid boxes is given in blue for runoff 11 and in orange for runoff 12 .

is highest for different combinations of all three regions, but after $2.8 \mathrm{Ma}$ a $50 \%$ contribution from regions 11 and 12 is again strongest, with no contribution from region 10 . Since region 10 is (far) more south and largely contains the African tropical forest, drainage from central Africa is also towards the Atlantic Ocean through the Congo River, which might clarify the lower influence of region 10 when combining the regions.

\section{Discussion and conclusions}

In this paper we have used simulations of the climate model CLIMBER-2 and analysed reconstructed climate variables from 3.2 to $2.3 \mathrm{Ma}$, a period that includes the PlioPleistocene transition. The model has been previously used to link orbital and climatic variability and is well suited for long-term transient climate simulations (e.g. Tuenter et al., 2005). During this time interval, the world experienced a large increase in $\mathrm{NH}$ glaciation, concurrent with a drawdown in atmospheric $\mathrm{CO}_{2}$ concentrations (Fig. 2). The CLIMBER2 simulations have been run over 5 million years and included ice sheet changes, atmospheric $\mathrm{CO}_{2}$ variations, and orbital parameters (Stap et al., 2018). We have looked at climate variability over the northern African continent and have linked transient variations of continental runoff to sedimentary records in the Mediterranean Sea and Atlantic Ocean.

The climatic variability in the model is largely determined by changes in the forcing records: $\mathrm{NH}$ and Antarctic ice sheets, atmospheric greenhouse gas forcing of $\mathrm{CO}_{2}$, and or- bital variations (Laskar et al., 2004). Both the timing and magnitude of the forcing will have an impact on the changes shown by the model. The ice sheet forcing imposed here is based on a 3D ice sheet model constrained by the LR04 benthic $\delta^{18} \mathrm{O}$ stack by Lisiecki and Raymo (2005), which also determined the age scale of the $\mathrm{CO}_{2}$ reconstructions. Ice sheet changes can be different but are constrained by the locations. On the other hand, $\mathrm{CO}_{2}$ is much less constrained since proxy data over this time period are sparse but reflect an amplitude of about 40-100 ppm (Martinez-Boti et al., 2015; de la Vega et al., 2020), and model-based reconstructions can be quite different (see, for example, Fig. 6 in Berends et al., 2020). Particularly, the reconstruction from Stap et al. (2016) shows a much larger amplitude in $\mathrm{CO}_{2}(80-150 \mathrm{ppm})$, whereas that from Willeit et al. (2019) employs a smaller amplitude (40-50 ppm) over our time period compared to our forcing record (60-80 ppm).

Simulated runoff over the northern African continent shows periodic behaviour largely related to the orbital frequencies of precession, although obliquity influence is also present, especially after inception of $\mathrm{NH}$ ice $(\sim 2.8 \mathrm{Ma})$. Previous studies have shown the strong presence of orbitally induced variations of the African monsoon that could originate from enhanced moisture transport from the tropical Atlantic (Bosmans et al., 2015a). From 3.2 to 2.3 Ma the variations are largely in sync with climatic precession. Obliquity variations are much less pronounced but do show an increase in the lag after inception of $\mathrm{NH}$ ice sheets at about 2.8 Ma. This is also related to the induced time lag increase in the LR04 age scale (Lisiecki and Raymo, 2005), which is the origin of the ice sheet and $\mathrm{CO}_{2}$ reconstructions used in the CLIMBER2 simulations (de Boer et al., 2014; Stap et al., 2018).

Although the evolution and dispersal of hominin species during this time could be linked to orbital variations (Joordens et al., 2019), a direct link to the climatic variations shown by CLIMBER-2 cannot be directly established.

The runoff output of northern Africa correlates exceptionally well with the $\mathrm{Ti} / \mathrm{Al}$ record of ODP Site 967, resulting in the correlation of sapropels S61-S80 with the corresponding wet runoff phases (Fig. 6). Although the correlation is high, peak values of $\mathrm{Ti} / \mathrm{Al}$ do not correspond exactly to low runoff, illustrating the non-linearity in the system that depends, for example, on wind transportation of aeolian dust and variable river flux of the Nile. Correlation with the dust record of ODP Site 659, which we re-tuned to the LR04 age scale, is moderate compared to that with the Ti/ $\mathrm{Al}$ record. The lower correlation with the dust could be expected since dust emissions are a strongly non-linear function of ground cover, wind, and soil moisture (e.g. Bauer and Ganopolski, 2010). Moreover, the hydrological cycle over the grid boxes is also clearly linked to the vegetation (Fig. 3). The vegetation shows a high correlation for trees and desert with $\mathrm{Ti} / \mathrm{Al}$ for the Sahel region ( -0.734 and 0.781 , respectively) and grass and desert for the Sahara region $(-0.783$ and 0.783$)$. In contrast, the correlation between vegetation coverage over 


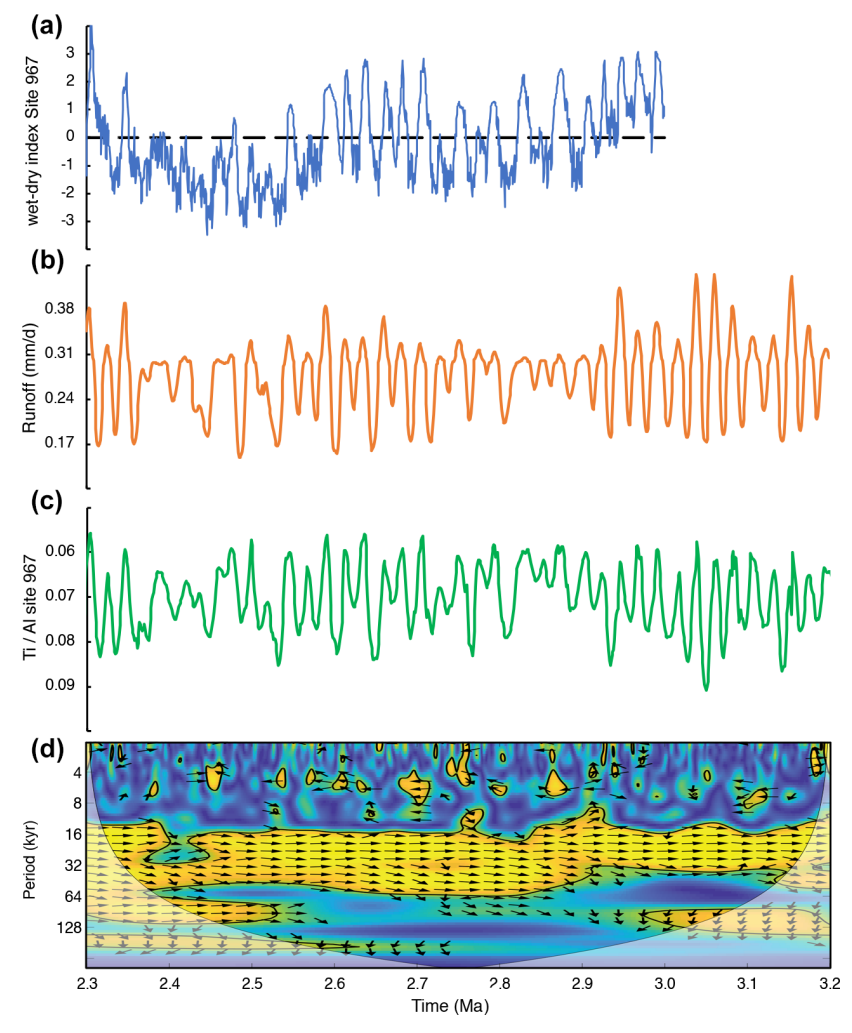

Figure 11. Records of African climate and Mediterranean sediments. (a) The wet-dry index as calculated by Grant et al. (2017) from Site 967, indicating wet and dry phases in northwest and eastern Africa. (b) The optimal runoff combined record of $35 \%$ runoff 11 plus $65 \%$ runoff 12 from CLIMBER-2. (c) The Ti/Al record from Site 967, with the $y$ axis reversed, and (d) a wavelet coherence diagram (Grinsted et al., 2004) of runoff with Ti/Al. The colour scale indicates coherence, with $>95 \%$ confidence levels indicated by the black lines (orange to yellow colours). The arrows indicate the phase, with right-pointing meaning in phase and upwardpointing mean a lead of runoff relative to $\mathrm{Ti} / \mathrm{Al}$.

the two regions is generally poor compared to the dust of Site 659 , illustrating the strong non-linear relationship between vegetation and dust outside the African continent.

The $\mathrm{Ti} / \mathrm{Al}$ record of the Mediterranean represents variation in the relative contribution of aeolian and fluvial dust input in the sediment core, relating high continental runoff from the African continent to lower values of the $\mathrm{Ti} / \mathrm{Al}$ record. Although overall correlation is best represented by runoff from the Sahel region, we found that combined runoff from the Sahel (grid box 11) and the Sahara (grid box 12) gives the highest correlation with the record. Hence, high fluvial input corresponds well to high runoff from the Sahel region, whereas more aeolian input corresponds to dry periods in the Sahara, corresponding to both low runoff and possible higher dust transport from the desert.

We correlated the combined runoff output of grid boxes 11 and 12 with the Ti/Al record. Over the entire period the correlation is highest for a record that combines $65 \%$ of grid box 12 (Sahara) with $35 \%$ of grid box 11 (Sahel) as presented in Fig. 11b. Although the data correlate fairly well with the wet-dry index reconstructed from the same site (Site 967; Grant et al., 2017) (Fig. 11a; correlation with Ti/Al is 0.49 , and with the combined runoff it is 0.45 ), the wet-dry index, representing northwest and eastern African climate, does show a much larger long-term (eccentricity) component not present in the $\mathrm{Ti} / \mathrm{Al}$ or runoff data. Furthermore, we have calculated a wavelet coherence diagram (Fig. 11d) indicating coherence of frequencies between the combined runoff from CLIMBER-2 and the Ti/Al record of Site 967 (Fig. 11b and $\mathrm{c}$, respectively). The arrows indicate that for precessional periods $(\sim 23 \mathrm{kyr})$ the records vary largely in phase from 3.2 to 2.3 Ma. Moreover, obliquity change increases slightly after $2.8 \mathrm{Ma}$.

We have shown that there is a clear uninterrupted impact of runoff on the Mediterranean, for which we showed that prior to $2.8 \mathrm{Ma}$ a higher contribution from the Sahara region is required for a better correlation with the $\mathrm{Ti} / \mathrm{Al}$ record. However, after inception of $\mathrm{NH}$ glaciation a $50 \%$ contribution from each of the regions represents the highest fit. It seems that prior to a more high-latitude influence of global climate, dry periods over the Sahara had more of an impact on the $\mathrm{Ti} / \mathrm{Al}$ record, i.e. during the relatively warm climate of the late Pliocene. After $\sim 2.8 \mathrm{Ma}$, the global cooling trend gives way to a more equal impact from the Sahel and the Sahara regions, whereas equatorial regions are much less linked to the variations seen in the Mediterranean. Moreover, it has previously been shown that river runoff from the south, in this case largely dominated by the Nile, is related to the strength of the North African monsoon (e.g. Bosmans et al., 2015b). There is a clear connection between northern African climate and the Mediterranean. Although the CLIMBER-2 model is of low resolution, it also shows a strong coherence with sedimentary records from the Mediterranean, especially for precessional frequencies.

Code availability. We have used output of the CLIMBER-2 model (available at https://doi.org/10.1002/2017PA003313; Stap et al., 2018).

Data availability. Model output and data used in this paper can be provided upon request to the corresponding author. Data is available on DataVerseNL through: https://doi.org/10.34894/HD6E9I (last acccess: 27 January 2021, de Boer et al., 2021).

Author contributions. BdB and MP carried out the analysis, and $\mathrm{BdB}$ wrote the paper with contributions from all authors. All authors contributed equally to the discussion and interpretation of the results. 
Competing interests. The authors declare that they have no conflict of interest.

Acknowledgements. We would like to thank Erik Tuenter for running the CLIMBER-2 simulations and making the data available. We would also like to thank Hans Brumsack and Rolf Wehausen for making the data from Site 967 available.

Financial support. Bas de Boer is funded through a grant from the SCOR Corporate Foundation for Science. This research was funded by an NWO-ALW grant (project number 865.10.001) and a Netherlands Earth System Science Centre Gravitation Programme grant (grant no. 024.002.001) to Lucas J. Lourens.

Review statement. This paper was edited by Erin McClymont and reviewed by two anonymous referees.

\section{References}

Bailey, I., Hole, G. M., Foster, G. L., Wilson, P. A., Storey, C. D., Trueman, C. N., and Raymo, M. E.: An alternative suggestion for the Pliocene onset of major northern hemisphere glaciation based on the geochemical provenance of North Atlantic Ocean ice-rafted debris, Quaternary Sci. Rev., 75, 181-194, 2013.

Bartoli, G., Hönisch, B., and Zeebe, R. E.: Atmospheric $\mathrm{CO}_{2}$ decline during the Pliocene intensification of Northern Hemisphere glaciations, Paleoceanography, 26, PA4213, https://doi.org/10.1029/2010PA002055, 2011.

Bauer, E. and Ganopolski, A.: Aeolian dust modeling over the past four glacial cycles with CLIMBER-2, Global Planet. Change, 74, 49-60, 2010.

Berends, C. J., de Boer, B., and van de Wal, R. S. W.: Reconstructing the Evolution of Ice Sheets, Sea Level and Atmospheric $\mathrm{CO}_{2}$ During the Past 3.6 Million Years, Clim. Past Discuss. [preprint], https://doi.org/10.5194/cp-2020-52, accepted, 2021.

Bintanja, R. and van de Wal, R. S. W.: North American ice-sheet dynamics and the onset of 100000 -year glacial cycles, Nature, 454, 869-872, https://doi.org/10.1038/nature07158, 2008.

Bosmans, J. H. C., Drijfhout, S. S., Tuenter, E., Hilgen, F. J., and Lourens, L. J.: Response of the North African summer monsoon to precession and obliquity forcings in the EC-Earth GCM, Clim. Dynam., 44, 279-297, https://doi.org/10.1007/s00382014-2260-z, 2015a.

Bosmans, J. H. C., Drijfhout, S. S., Tuenter, E., Hilgen, F. J., Lourens, L. J., and Rohling, E. J.: Precession and obliquity forcing of the freshwater budget over the Mediterranean, Quaternary Sci. Rev., 123, 16-30, https://doi.org/10.1016/j.quascirev.2015.06.008, 2015b.

Brigham-Grette, J., Melles, M., Minyuk, P., Andreev, A., Tarasov, P., DeConto, R., Koenig, S., Nowaczyk, N., Wennrich, V., Rosén, P., Haltia, E., Cook, T., Gebhardt, C., Meyer-Jacob, C., Snyder, J., and Herzschuh, U.: Pliocene Warmth, Polar Amplification, and Stepped Pleistocene Cooling Recorded in NE Arctic Russia, Science, 340, 1421-1427, https://doi.org/10.1126/science.1233137, 2013.
Brovkin, V., Ganopolski, A., and Svirezhev, Y.: A continuous climate-vegetation classification for use in climate-biosphere studies, Ecol. Model., 101, 251-261, 1997.

Caley, T., Extier, T., Collins, J. A., Schefuß, E., Dupont, L., Malaizé, B., Rossignol, L., Souron, A., McClymont, E. L., JimenezEspejo, F. J., García-Comas, C., Eynaud, F., Martinez, P., Roche, D. M., Jorry, S. J., Charlier, K., Wary, M., Gourves, P.-Y., Billy, I., and Giraudeau, J.: A 2 million year-long hydroclimatic context for hominin evolution in southeastern Africa, Nature, 560, 76-79, 2018.

de Boer, B., Lourens, L. J., and van de Wal, R. S. W.: Persistent 400000 -year variability of Antarctic ice volume and the carbon cycle is revealed throughout the Plio-Pleistocene, Nat. Commun., 5, 2999, https://doi.org/10.1038/ncomms3999, 2014.

de Boer, B., Peters, M., and Lourens, L. J.: The transient impact of the African monsoon on Plio-Pleistocene Mediterranean sediments, available at: https://doi.org/10.34894/HD6E9I, last access: 27 January 2021.

de la Vega, E., Chalk, T. B., Wilson, P. A., Bysani, R. P., and Foster, G. L.: Atmospheric $\mathrm{CO}_{2}$ during the Mid-Piacenzian Warm Period and the M2 glaciation, Sci. Rep., 10, 11002 , https://doi.org/10.1038/s41598-020-67154-8, 2020.

deMenocal, P. B.: Plio-Pleistocene African Climate, Science, 270, 53-59, https://doi.org/10.1126/science.270.5233.53, 1995.

DiMaggio, E., Campisano, C., Rowan, J., Dupont-Nivet, G., Deino, A., Bibi, F., Lewis, M., Souron, A., Garello, D., Werdelin, L., Reed, K., and Arrowsmith, J.: Late Pliocene fossiliferous sedimentary record and the environmental context of early Homo from Afar, Ethiopia, Science, 347, 1355-1359, https://doi.org/10.1126/science.aaa1415, 2015.

Donges, J. F., Donner, R. V., Trauth, M. H., Marwan, N., Schellnhuber, H.-J., and Kurths, J.: Nonlinear detection of paleoclimatevariability transitions possibly related to human evolution, $\mathrm{P}$. Natl. Acad. Sci. USA, 108, 20422-20427, 2011.

Emeis, K., Robertson, A., and Richter, C.: Proceedings of the Ocean Drilling Program (ODP), Initial Reports, College Station, Texas, 160, https://doi.org/10.2973/odp.proc.ir.160.1996, 1996.

Flesche Kleiven, H., Jansen, E., Fronval, T., and Smith, T.: Intensification of Northern Hemisphere glaciations in the circum Atlantic region (3.5-2.4 Ma) - ice-rafted detritus evidence, Palaeogeogr. Palaeocl., 184, 213-223, https://doi.org/10.1016/S00310182(01)00407-2, 2002.

Ganopolski, A. and Calov, R.: The role of orbital forcing, carbon dioxide and regolith in $100 \mathrm{kyr}$ glacial cycles, Clim. Past, 7, 1415-1425, https://doi.org/10.5194/cp-7-1415-2011, 2011.

Grant, K. M., Rohling, E. J., Westerhold, T., Zabel, M., Heslop, D., Konijnendijk, T., and Lourens, L.: A 3 million year index for North African humidity/aridity and the implication of potential pan-African Humid periods, Quaternary Sci. Rev., 171, 100-118, 2017.

Grinsted, A., Moore, J. C., and Jevrejeva, S.: Application of the cross wavelet transform and wavelet coherence to geophysical time series, Nonlin. Processes Geophys., 11, 561-566, https://doi.org/10.5194/npg-11-561-2004, 2004.

Hays, J., Imbrie, J., and Shackleton, N.: Variation in the Earth's orbit: pacemakers of the ice ages, Science, 194, 1121-1132, 1976.

Herbert, T. D., Peterson, L. C., Lawrence, K. T., and Liu, Z.: Tropical Ocean Temperatures Over the Past 3.5 Million Years, Sci- 
ence, 328, 1530-1534, https://doi.org/10.1126/science.1185435, 2010.

Hilgen, F.: Astronomical calibration of Gauss to Matuyama sapropels in the Mediterranean and implication for the geomagnetic polarity time scale, Earth Planet. Sc. Lett., 104, 226-244, 1991.

Joordens, J. C. A., Feibel, C. S., Vonhof, H. B., Schulp, A. S., and Kroon, D.: Relevance of the eastern African coastal forest for early hominin biogeography, J. Hum. Evol., 131, 176-202, https://doi.org/10.1016/j.jhevol.2019.03.012, 2019.

Konijnendijk, T., Ziegler, M., and Lourens, L.: Chronological constraints on Pleistocene spropel depositions from highresoution geochemical records of ODP Sites 967 and 968, Newsl. Stratigr., 47, 263-282, https://doi.org/10.1127/00780421/2014/0047, 2014.

Kroon, D., Alexander, I., Little, M., Lourens, L. J., Matthewson, A., Robertson, A. H. F., and Sakamoto, T.: Oxygen isotope and sapropel stratigraphy in the eastern Mediterranean during the last 3.2 million years, Proceedings of the Ocean Drilling Program, Scientific Results, 160, 181-189, 1998.

Kuechler, R. R., Dupont, L. M., and Schefuß, E.: Hybrid insolation forcing of Pliocene monsoon dynamics in West Africa, Clim. Past, 14, 73-84, https://doi.org/10.5194/cp-14-73-2018, 2018.

Laskar, J., Robutel, P., Joutel, F., Gastineau, M., Correia, A., and Levrard, B.: A long-term numerical solution for the insolation quantities of the Earth, Astron. Astrophys., 428, 261-285, https://doi.org/10.1051/0004-6361:20041335, 2004.

Lisiecki, L. and Raymo, M.: A Pliocene-Pleistocene stack of 57 globally distributed benthic $\delta^{18} \mathrm{O}$ records, Paleoceanography, 20, PA1003, https://doi.org/10.1029/2004PA001071, 2005.

Lisiecki, L. and Raymo, M.: Plio-Pleistocene climate evolution: trends and transitions in glacial cycle dynamics, Quaternary Sci. Rev., 26, 56-69, 2007.

Lourens, L. J., Antonarakou, A., Hilgen, F. J., Hoof, A. A. M. V., Vergnaud-Grazzini, C., and Zachariasse., W. J.: Evolution of the Plio-Pleistocene astronomical timescale, Paleoceanography, 11, 391-413, 1996.

Lourens, L. J., Wehausen, R., and Brumsack, H. J.: Geological constraints on tidal dissipation and dynamical ellipticity of the Earth over the past three million years, Nature, 409, 1029-1033, https://doi.org/10.1038/35059062, 2001.

Lourens, L. J., Becker, J., Bintanja, R., Hilgen, F. J., Tuenter, E., van de Wal, R. S. W., and Ziegler, M.: Linear and non-linear response of late Neogene glacial cycles to obliquity forcing and implications for the Milankovitch theory, Quaternary Sci. Rev., 29, 352-365, https://doi.org/10.1016/j.quascirev.2009.10.018, 2010.

Lupien, R. L., Russell, J. M., Feibel, C., Beck, C., Castañeda, I., Deino, A., and Cohen, A. S.: A leaf wax biomarker record of early Pleistocene hydroclimate from West Turkana, Kenya, Quaternary Sci. Rev., 186, 225-235, 2018.

Lüthi, D., Le Flock, M., Bereiter, B., Blunier, T., Barnola, J.-M., Siegenthaler, U., Raynaud, D., Jouzel, J., Fischer, H., Kawamura, K., and Stocker, T.: High-resolution carbon dioxide concentration record $650000-800000$ years before present, Nature, 453, 379-382, https://doi.org/10.1038/nature06949, 2008.

Martinez-Boti, M. A., Foster, G. L., Chalk, T. B., Rohling, E. J., Sexton, P. F., Lunt, D. J., Pancost, R. D., Badger, M. P. S., and Schmidt, D. N.: Plio-Pleistocene climate sensitivity evaluated using high-resolution $\mathrm{CO}_{2}$ records, Nature, 518, 49-54, 2015.
Maslin, M. A., Brierley, C. M., Milner, A. M., Shultz, S., Trauth, M. H., and Wilson., K. E.: East African climate pulses and early human evolution, Quaternary Sci. Rev., 101, 1-17, https://doi.org/10.1016/j.quascirev.2014.06.012, 2014.

Mounier, A. and Mirazón Lahr, M.: Deciphering African late middle Pleistocene hominin diversity and the origin of our species, Nat. Commun., 10, 3406, https://doi.org/10.1038/s41467-01911213-w, 2019.

Paillard, D., Labeyrie, L., and Yiou, P.: Macintosh program performs time-series analysis, Eos Trans. AGU, 77, 379, https://doi.org/10.1029/96EO00259, 1996.

Petoukhov, V., Ganopolski, A., Brovkin, V., Claussen, M., Eliseev, A., Kubatzki, C., and Rahmstorf., S.: CLIMBER-2: A climate system model of intermediate complexity, part I: Model description and performance for present climate, Clim. Dynam., 16, 117, https://doi.org/10.1007/PL00007919, 2000.

Rose, C., Polissar, P. J., Tierney, J. E., Filley, T., and deMenocal, P. B.: Changes in northeast African hydrology and vegetation associated with Pliocene-Pleistocene sapropel cycles, Philos. T. Roy. Soc. B., 371, 20150243 , https://doi.org/10.1098/rstb.2015.0243, 2016.

Stap, L. B., van de Wal, R. S. W., de Boer, B., Bintanja, R., and Lourens, L. J.: Interaction of ice sheets and climate during the past 800000 years, Clim. Past, 10, 2135-2152, https://doi.org/10.5194/cp-10-2135-2014, 2014.

Stap, L. B., de Boer, B., Ziegler, M., Bintanja, R., Lourens, L. J., and van de Wal, R. S. W.: $\mathrm{CO}_{2}$ over the past 5 million years: Continuous simulation and new $\delta^{11} \mathrm{~B}$-based proxy data, Earth Planet. Sc. Lett., 439, 1-10, 2016.

Stap, L. B., van de Wal, R. S. W., de Boer, B., Köhler, P., Hoencamp, J. H., Lohmann, G., Tuenter, E., and Lourens, L. J.: Modeled Influence of Land Ice and $\mathrm{CO}_{2}$ on Polar Amplification and Paleoclimate Sensitivity During the Past 5 Million Years, Paleoceanography and Paleoclimatology, 33, 381394, https://doi.org/10.1002/2017PA003313, 2018.

Stocker, T. F., Wright, D. G., and Mysak, L. A.: A zonally averaged, coupled ocean-atmosphere model for paleoclimate studies, J. Climate, 5, 773-797, 1992.

Tan, N., Ladant, J.-B., Ramstein, G., Dumas, C., Bachem, P., and Jansen, E.: Dynamic Greenland ice sheet driven by $\mathrm{pCO}_{2}$ variations across the Pliocene Pleistocene transition, Nat. Commun., 9, 4755, https://doi.org/10.1038/s41467-018-07206-w, 2018.

Tiedemann, R., Samthein, M., and Shackleton, N. J.: Astronomic timescale for the Pliocene Atlantic $\delta^{18} \mathrm{O}$ and dust flux records of Ocean Drilling Program site 659, Paleoceanography, 9, 619-638, 1994.

Trauth, M., Maslin, M., Deino, A., Strecker, M., Bergner, A., and Duhnforth, M.: High- and low-latitude forcing of PlioPleistocene East African climate and human evolution, J. Hum. Evol., 53, 475-486, 2007.

Tuenter, E., Weber, S. L., Hilgen, F. J., Lourens, L. J., and Ganopolski., A.: Simulation of climate phase lags in response to precession and obliquity forcing and the role of vegetation., Clim. Dynam., 24, 279-295, https://doi.org/10.1007/s00382-004-0490-1, 2005.

van de Wal, R. S. W., de Boer, B., Lourens, L. J., Köhler, P., and Bintanja, R.: Reconstruction of a continuous high-resolution $\mathrm{CO}_{2}$ record over the past 20 million years, Clim. Past, 7, 1459-1469, https://doi.org/10.5194/cp-7-1459-2011, 2011. 
Venti, N. L., Billups, K., and Herbert, T. D.: Increased sensitivity of the Plio-Pleistocene northwest Pacific to obliquity forcing, Earth Planet. Sc. Lett., 384, 121-131, https://doi.org/10.1016/j.epsl.2013.10.007, 2013.

Wagner, B., Vogel, H., Francke, A., Friedrich, T., Donders, T., Lacey, J. H., Leng, M. J., Regattieri, E., Sadori, L., Wilke, T., Zanchetta, G., Albrecht, C., Bertini, A., Combourieu-Nebout, N., Cvetkoska, A., Giaccio, B., Grazhdani, A., Hauffe, T., Holtvoeth, J., Joannin, S., Jovanovska, E., Just, J., Kouli, K., Kousis, I., Koutsodendris, A., Krastel, S., Lagos, M., Leicher, N., Levkov, Z., Lindhorst, K., Masi, A., Melles, M., Mercuri, A. M., Nomade, S., Nowaczyk, N., Panagiotopoulos, K., Peyron, O., Reed, J. M., Sagnotti, L., Sinopoli, G., Stelbrink, B., Sulpizio, R., Timmermann, A., Tofilovska, S., Torri, P., Wagner-Cremer, F., Wonik, T., and Zhang, X.: Mediterranean winter rainfall in phase with African monsoons during the past 1.36 million years, Nature, 573, 256-260, https://doi.org/10.1038/s41586-019-1529-0, 2019.
Wang, P., Tian, J., and Lourens, L. J.: Obscuring of long eccentricity cyclicity in Pleistocene oceanic carbon isotope records, Earth Planet. Sc. Lett., 290, 319-330, 2010.

Wehausen, R. and Brumsack, H.-J.: Chemical cycles in Pliocene sapropel-bearing and sapropel-barren eastern Mediterranean sediments, Palaeogeogr. Palaeoclimatol. Palaeoecol., 158, 325-352, 2000.

Willeit, M., Ganopolski, A., Calov, R., Robinson, A., and Maslin, M.: The role of $\mathrm{CO}_{2}$ decline for the onset of Northern Hemisphere glaciation, Quaternary Sci. Rev., 119, 22-34, https://doi.org/10.1016/j.quascirev.2015.04.015, 2015.

Willeit, M., Ganopolski, A., Calov, R., and Brovkin, V.: MidPleistocene transition in glacial cycles explained by declining $\mathrm{CO}_{2}$ and regolith removal, Sci. Adv., 5, eaav7337, https://doi.org/10.1126/sciadv.aav7337, 2019. 